\title{
PENGUKURAN KEJAYAAN BANTUAN MODAL PERNIAGAAN USAHAWAN ASNAF DALAM KONTEKS PENCAPAIAN MAQATSID AL-SHARI' $A H$ : KAJIAN DI DAERAH KUALA TERENGGANU DAN KUALA NERUS, TERENGGANU
}

\section{The Measurement of Asnaf Business Capital Assistance in the Context of Maqāssid al-Sharī'ah: A Study at Kuala Terengganu and Kuala Nerus, Terengganu}

\author{
Nurmaizura Marzuki ${ }^{1}$ \\ Solehuddin Zulkifli \\ Hairunnizam Wahid ${ }^{3}$
}

\begin{abstract}
One type of assistance that was granted by the management and administration of zakāh to ensure that the entrepreneur recipients can improve their living standards is by assistance in the form of business capital. Capital grants are expected to generate longterm income and help to transform them to be an entrepreneur and then can also turn them to become a payer of zakāh instead
\end{abstract}

1 Master Candidate, Faculty of Economics and Management, The National University of Malaysia, Bangi, nurmaizuramarzuki@gmail.com

2 Master Candidate, Faculty of Economics and Management, The National University of Malaysia, Bangi, nuruddin_alranini90@yahoo.com.my

3 Senior Lecturer, School of Economics, Faculty of Economics and Management, The National University of Malaysia, Bangi, hairun@ukm.edu.my 
of recipients. Nevertheless, it is often claimed that the assistance is not channelled effectively from the economic angle. Many beneficiaries have failed and the main reason given is a problem related to the capital. Therefore, this study was to identify factors other than capital that can influence the success or failure of the business undertaken by these entrepreneurs recipients. In order to measure the achievement of business success undertaken by these entrepreneurs recipients, the study takes into consideration two aspects of dependent variables based on income and maqāsid al-shari' 'ah. This study used a sample of respondents from the entrepreneur recipients who received business capital assistance in the state capital of Kuala Terengganu and Kuala Nerus. A total of 140 respondents were surveyed and analyzed using analysis of regression logistic. Specifically, capital assistance has seen a modest achievement in religion, life, intellect, lineage and property. Findings shows that the success of the business conducted is influenced significantly by age and duration of trade. Hence, the important implication of this study is the finding; assessment should not focus only on the aspect of capital, but important factors that should also be included and other features.

Keywords: entrepreneurs recipients, capital assistance

\section{PENGENALAN}

Konsep maqāṣid al-sharī' ah sering dikaitkan dalam kehidupan seorang Muslim dalam semua aspek termasuk isu pengurusan zakat. Pemahaman maqāșid alsharī'ah dapat dilihat melalui kenyataan tokoh ilmu maqāșid seperti al-Tahir ibn Ashur menyatakan ilmu maqāṣid adalah menyeluruh untuk memastikan keadilan, kesaksamaan dan juga pemeliharaan fitrah manusia. Yūsuf alQaraḍāwī juga ada menyatakan konsep maqāṣid adalah untuk menjaga maruah diri seseorang.

Maqāṣid al-sharī'ah bermaksud objektif pensyariatan yang ingin dicapai oleh syarak berasaskan dalil-dalil kulliy untuk kemaslahatan umum. Maqāsid al-sharī'ah yang ingin dicapai ini perlu menjadi tonggak dan hala tuju di dalam pensyariatan hukum-hakam dan ajaran Islam. Pemahaman dan penggunaan kaedah maqāsid al-sharī'ah merupakan unsur penting bagi setiap mujtahid dalam proses berijtihad dan pengaplikasian hukum syarak ke alam realiti dan kehidupan semasa, yang bersesuaian dengan kehendak dan tujuan pensyariatan ajaran Islam yang diturunkan. Tinjauan terhadap kedudukan maqāṣid al- 
Pengukuran Kejayaan Bantuan Modal Perniagaan Usahawan Asnaf dalam Konteks Pencapaian Maqāșid al-Sharī'ah: Kajian di Daerah Kuala Terengganu dan Kuala Nerus, Terengganu

sharī'ah menurut perspektif syarak, menunjukkan setiap dalil syariat Islam dan hukumnya mempunyai maqāssid dan matlamat yang tertentu. ${ }^{4}$

Zakat adalah salah satu daripada lima tunjang yang menjadi asas kepada Islam selain solat, haji dan berpuasa di bulan Ramadan. Selain daripada menjadi tanggungjawab ibadat yang wajib dilakukan oleh semua umat Islam, zakat turut berperanan sebagai medium pengagihan nikmat kekayaan sesama masyarakat dan cara membasmi masalah kemiskinan yang paling berkesan sekiranya dilakukan secara telus dan ikhlas. Kepelbagaian fungsi zakat ini telah meletakkan di kedudukan yang unik. Dengan kedudukan ini, zakat boleh disifatkan sebagai ibadat dalam bentuk pembiayaan. Berdasarkan kedudukannya inilah juga zakat tidak hanya diperkatakan oleh para fuqaha dalam bab ibadat semata-mata, tetapi juga dinyatakan pada bab pengurusan harta, sosial, kebajikan, jihad dan pemerintahan atau siyāsah. ${ }^{5}$

Malaysia mencatat kutipan zakat yang agak tinggi iaitu kira-kira RM400 juta setahun iaitu peningkatan tujuh kali ganda daripada RM61 juta pada tahun 1991 kepada RM473 juta pada tahun 2004 dengan sebahagian besar kutipan tertumpu di Selangor dan Wilayah Persekutuan. Manakala, menurut kenyataan akhbar, pencapaian agihan dan kutipan zakat negeri Selangor 2015 adalah antara yang tertinggi di negara ini dengan jumlah RM626.6 juta berbanding RM582.3 juta pada tahun sebelumnya, dengan agihan zakat melebihi RM600 juta. ${ }^{6}$ Tetapi, yang menghairankan saban hari media melaporkan keadaan kemiskinan dan kefakiran ramai orang Islam di seluruh pelosok negara sehingga menggambarkan pengagihan semasa zakat menghadapi situasi kritikal dan tidak berkesan.

Nampaknya, kebanyakan institusi zakat lebih menekankan aspek pengutipan atau pungutan. Malah, ada negeri di Malaysia menubuhkan jabatan khas untuk tujuan kutipan sahaja manakala, urusan pengagihan diserahkan kepada Majlis Agama Islam Negeri. Kaedah pengagihan zakat masih menumpukan kepada bentuk bayaran pindahan berkala yang tidak mampu menyelesaikan masalah kemiskinan masyarakat Islam. Konsep agihan semasa ini perlu disegarkan dengan pendekatan-pendekatan lain yang lebih berkemampuan melahirkan usahawan dalam kalangan asnaf untuk berdikari dan mampu menyara diri dan keluarga. Projek ekonomi dan perniagaan dilihat sebagai projek ini bertujuan

4 Al-Raysun̄̄, Aḥmad, Nazariyyat al-Maqāṣid 'ind al-Imām al-Shātibī (Kaherah: Dār al-Kalimah, 2015), 5.

5 Mahmood Zuhdi, Pengurusan Zakat (Kuala Lumpur: Dewan Bahasa dan Pustaka, 2003), 17.

6 Ahmad Fadzly Esa, 'LZS Sasar Kutipan, Agihan Zakat RM645 juta,'Berita Harian Online, 4 Februari 2016. 
untuk melahirkan usahawan Muslim yang berdaya saing dan menggerakkan ekonomi umat Islam secara tidak langsung.

Bantuan kewangan dalam bentuk modal perniagaan kepada golongan usahawan asnaf dilihat sebagai lebih bermanfaat berbanding bantuan kewangan untuk saraan. Pertamanya, bantuan modal perniagaan boleh memberi peluang pekerjaan. Projek ini turut mengembangkan potensi mereka dalam beberapa aspek, walaupun rata-ratanya tidak berpendidikan sempurna. Bantuan modal perniagaan juga bersifat produktif kerana ia memenuhi keperluan golongan usahawan asnaf dan hasilnya mereka tidak lagi memerlukan wang zakat dalam bentuk saraan. Y.A.B. Dato' Seri Abdullah Ahmad Badawi, mantan Perdana Menteri Malaysia ke-5, semasa perasmian Persidangan Zakat Antarabangsa 2006, antara lain menyarankan agar dana zakat tidak hanya dilihat sebagai badan kebajikan atau sebagai bantuan tujuan jangka pendek kepada mereka yang memerlukan, sebaliknya ia perlu digunakan bagi matlamat jangka panjang sehingga membolehkan mereka berupaya menjaga kebajikan diri sendiri di masa akan datang. ${ }^{7}$

Agihan zakat terutama bantuan modal perniagaan perlu dinilai keberkesanannya terutamanya dari segi keupayaannya melahirkan golongan usahawan asnaf yang mampu berdikari dan memperbaiki taraf sosioekonomi. Menilai keberkesanan sesuatu program yang bertujuan meningkatkan taraf sosioekonomi kepada golongan sasaran adalah penting dan perlu dilakukan. ${ }^{8}$ Penilaian keberkesanan penting bagi tujuan melihat prestasi program ${ }^{9}$ mengenal pasti masalah, kelemahan dan memperbaiki prestasi program. ${ }^{10}$ Dalam menilai keberkesanan sesuatu program pembangunan terutama untuk golongan fakir dan miskin mengambil kira pelbagai faktor sama ada aspek ekonomi mahupun aspek sosial mengikut perspektif barat semata-mata dan agak sukar ditemui kajian yang menjurus kepada perspektif kajian dari sudut pandangan Islam. Selain itu, penilaian yang berasaskan hanya ke atas pendapatan tidak memberikan penilaian yang saksama keperluan manusia. Mereka yang menilai keberkesanan zakat dari sudut ini akan mengehadkan pengagihan bantuan kepada penerima dan dengan itu membantu mereka dari segi bantuan kewangan sahaja. Walau bagaimanapun, selain daripada wang,

$7 \quad$ Pusat Pungutan Zakat, Majlis Agama Islam Wilayah Persekutuan, Laporan Zakat (Kuala Lumpur: Daruzzakah, 2006), 135.

8 Rossi, P.H., Lipsey, M.W \& Freaman, H.E., Evaluation A Systematic Approach, $7^{\text {th }}$ ed. (California: Sage Publishers, Inc, 2004), 22.

9 Ahmad Mahdzan Ayob, Perancangan dan Penilaian Projek Pembangunan (Kuala Lumpur: Dewan Bahasa dan Pustaka, 1989), 213.

10 Xavier, John Antony, Effective Evaluation: A Practical Guide (Kuala Lumpur: National Institute of Public Administration (INTAN), 2000), 1-3. 
Pengukuran Kejayaan Bantuan Modal Perniagaan Usahawan Asnaf dalam Konteks Pencapaian Maqāṣid al-Sharī‘ah: Kajian di Daerah Kuala Terengganu dan Kuala Nerus, Terengganu

manusia juga perlu lain-lain bentuk bantuan seperti agama, pengetahuan, hidup selesa, keluarga dan bersosial, antara lain yang sebenarnya seiring dengan kehendak dan matlamat syarak dalam kehidupan individu Muslim yang dikenali sebagai maqāșid al-sharī'ah. Justeru kejayaan asnaf dalam memenuhi maqāșid al-sharī'ah juga perlu diberikan perhatian agar sikap asnaf dapat diubah menjadi ke arah yang produktif dan bersedia mengubah diri sendiri menjadi lebih positif. Namun masalah utama kebanyakan golongan ini adalah untuk mendapatkan modal bagi memulakan perniagaan. ${ }^{11}$ Modal berperanan sebagai satu jentera pentadbiran sosial yang cepat, mudah dan efisien yang membolehkan golongan miskin memecahkan kemelut kemiskinan melalui usaha mereka sendiri. Modal membolehkan isi rumah termiskin memulakan dan mengembangkan keusahawanan dan kemahiran hidup mereka ke arah peningkatan pendapatan dan taraf hidup. Lantaran itu, apabila berlaku kegagalan maka ia akan dikaitkan dengan modal iaitu kekurangan modal perniagaan. Program bantuan modal zakat adalah antara program yang telah diketengahkan oleh pihak institusi zakat bagi menangani masalah ini.

Persoalan utama kajian ini ialah sejauh manakah usahawan asnaf yang menerima bantuan modal zakat ini telah dianggap berjaya dan sejauh manakah pencapaian asnaf ini dalam memenuhi maqāṣid al-sharī'ah iaitu menjaga agama (ad-din), menjaga nyawa (al-nafs), menjaga aqal dan fikiran (al-'aql), menjaga maruah dan keturunan (al-nasl) dan menjaga harta (almal) telah tercapai. Adakah benar bahawa kekurangan modal menjadi punca utama kegagalan perniagaan dalam kalangan usahawan asnaf. Justeru itu, kajian ini bertujuan untuk mengkaji kejayaan asnaf daripada sudut maqāșid al-sharī'ah serta menguji beberapa faktor yang dijangkakan mempengaruhi kejayaan atau kegagalan perniagaan yang diusahakan oleh usahawan asnaf ini. Pengenalpastian tersebut akan dapat membantu pihak zakat dalam mengukur kejayaan usahawan asnaf daripada sudut maqāṣid al-sharī'ah serta mengenalpasti strategi tertentu untuk membantu usahawan asnaf untuk terus berjaya dalam bidang perniagaan.

\section{KAJIAN LITERATUR}

Kajian terhadap faktor kejayaan usahawan umumnya tertumpu kepada dua aspek utama iaitu faktor dalaman dan faktor luaran. Faktor dalaman adalah aspek individu usahawan manakala faktor luaran ialah aspek struktur dan

11 Sukor Kasim, 'Peranan Modal dalam Membasmi Kemiskinan,' (Kertas Kerja, Konvensyen Ekonomi Bumiputera; Prestasi Kini dan Cabaran Selepas 1990, 1213 November 1990). 
persekitaran perniagaan. ${ }^{12}$ Ciri dalaman yang merupakan ciri individu yang boleh membentuk sifat keusahawanan individu bagi memastikan kejayaan ialah gaya hidup dan budaya pergaulan harian. Misalnya Kets de Vries \& Manfred ${ }^{13}$ menyatakan bahawa ciri peribadi usahawan terbentuk hasil daripada kesusahan hidup yang dilalui. Kesusahan ini menjana perasaan ingin maju yang perlu dimiliki oleh seorang usahawan. Delmar ${ }^{14}$ pula menyatakan bahawa ciri peribadi ialah merangkumi kemampuan menghadapi risiko, kebolehan mengawal diri, keyakinan serta sifat ingin berdikari. Mamat ${ }^{15}$ menyatakan matlamat merupakan penentu utama kepada lahirnya sikap positif dalam diri usahawan untuk berjaya dan tidak mudah berpuas hati dengan kejayaan yang dicapai. Lamsa et al. ${ }^{16}$ pula menyatakan bahawa komitmen terhadap perniagaan amat berkait rapat dengan pembangunan personaliti dalam perkembangan perniagaan. Kualiti dalaman tersebut adalah amat diperlukan dan perlu dimiliki oleh asnaf untuk memungkinkan mereka berjaya.

Daripada aspek dan faktor luaran pula Martinelli ${ }^{11}$ percaya bahawa aspek budaya dan sokongan institusi boleh menggalakkan pembentukan usahawan. Begitu juga faktor pengetahuan mengenai institusi, perundangan, pengetahuan bagaimana memulakan perniagaan, bagaimana mendapatkan pinjaman amat mempengaruhi dalam pembentukan keusahawanan. ${ }^{17}$ Kajian tempatan seperti Zuraini ${ }^{18}$ mendapati faktor yang mempengaruhi kejayaan usahawan bumiputera ialah pengetahuan dalam perniagaan, sikap, motivasi untuk

12 Martinelli, A., Entrepreneurs and Management. In: Sociology (Princeton, N.J.: Princeton University Press, 1994).

13 Kets de Vries \& Manfred, F. R, 'The Entrepreneurial Personality: A Person at the Cross Roads', Journal of Managerial Studies, vol. 14/1 (1977): 34-57.

14 Delmar, F., 'The Psychology of the Entrepreneur,' in Enterprise and Small Business: Principles, Practice and Policy, ed. S. Carter \& D. Jones-Evans (Harlow: Financial Times, 2000), 161-162.

15 Rahmah Ismail et al., Daya Saing Usahawan dan Syarikat Melayu dalam Sektor Pembuatan dan Perkhidmatan (Kuala Lumpur: Dewan Bahasa dan Pustaka, 2006).

16 Lamsa, A. M., \& Savolainen, T., 'The Nature of Managerial Commitment to Strategies Change,' Journal of Leadership \& Organization Development, vol. 21/6 (2000): 102-119.

17 Busenitz, L. W., Gomez, C. \& Spencer, J. W., 'Country institutional profiles: Unlocking entrepreneurial phenomena', Academy of Management Journal, 43/5 (2002): 994-1003.

18 Zuraini Zakaria, 'Faktor-faktor yang Mempengaruhi Kemampuan Usahawan Bumiputera di kawasan Sungai Petani Kedah dalam Memajukan Perniagaan Mereka,' (Latihan Ilmiah, Sarjana Muda, Universiti Teknologi Malaysia, Skudai, 2000). 
Pengukuran Kejayaan Bantuan Modal Perniagaan Usahawan Asnaf dalam Konteks Pencapaian Maqāșid al-Sharī'ah: Kajian di Daerah Kuala Terengganu dan Kuala Nerus, Terengganu

berjaya, serta pengetahuan tentang modal dan bahan input yang diperlukan, amat mempengaruhi prestasi perniagaan. Begitu juga. latar belakang keluarga yang terlibat dalam perniagaan berhubung positif dengan kejayaan usahawan. ${ }^{19}$

Selain itu, pembiayaan modal merupakan aspek yang paling rumit dalam memulakan perniagaan. ${ }^{20}$ Kekurangan pembiayaan merupakan punca utama sebuah perusahaan kecil gagal. Tanpa pembiayaan yang mencukupi seseorang usahawan kecil tidak mampu untuk membeli dan menyenggarakan kemudahan, mengambil pekerja, menghasilkan dan memasarkan produk. ${ }^{21}$ Kajian yang telah dibuat berkaitan kecukupan saiz bantuan modal, menyatakan bahawa faktor kecukupan saiz modal mempunyai hubungan yang positif dengan kejayaan sesebuah perniagaan..$^{22}$ Manakala, berdasarkan satu kajian oleh Lussuer terhadap seratus orang usahawan Amerika Syarikat yang telah gagal dalam perniagaan mereka menunjukkan bahawa mereka gagal akibat dari faktor kekurangan modal, kos tetap yang tinggi dan masalah kemelesetan ekonomi. ${ }^{23}$

Bentuk bantuan zakat yang dikaji lebih menjurus kepada bantuan yang diterima dalam bentuk tidak produktif seperti bantuan saraan bulanan yang menunjukkan bahawa bantuan berkenaan masih belum dapat memberikan impak yang mencukupi dari segi meningkatkan taraf kehidupan golongan fakir dan miskin ${ }^{24}$ walaupun terdapat juga kajian yang menunjukkan ia berjaya mengurangkan kemiskinan dan mengurangkan jurang pendapatan. ${ }^{25}$ Selain itu, kajian yang dijalankan mengenai faktor yang menyumbang kepada kejayaan

19 Norashidah Hashim, Norsiah Othman \& Noraishah Buang, 'Konsep Kesediaan Keusahawanan Berdasarkan Kajian Kes Usahawan Industri Kecil dan Sederhana (IKS) di Malaysia’, Jurnal Pendidikan Malaysia, vol. 34/1 (2009): 187-203.

20 Ang, James S, 'Small Business Uniqueness and the Theory of Financial Management,' Journal of Small Business Finance, vol. 1/1 (1991): 11-13.

21 Byrd, M. J. \& Megginson, L. C, Small Business Managament: An Entrepreneur's Guidebook, $7^{\text {rd }}$ ed. (New York: Irwan McGraw-Hill, 2013), 10-12.

22 Norsidah Ahmad, 'Factors Affecting Business Performance of Malay Women Entrepreneurs in the Klang Valley,' (Master Dissertation, Universiti Sains Malaysia, Pulau Pinang, 1999).

23 Rohaizat Baharun, 'Kejayaan Para Usahawan Daripada Perspektif Penyelidikan,' Dewan Ekonomi (Januari, 2000), 36-37.

24 Hairunnizam Wahid, Sanep Ahmad, \& Radiah Abdul Kader, 'Pengaruh Faktor Keagamaan Terhadap Kualiti Hidup Individu: Kajian Kes Asnaf Fakir dan Miskin,' (Kertas kerja, Seminar Kebangsaan MACFEA ke-14: Hala tuju Penyelidikan Kepenggunaan, 13-14 Julai 2010).

25 Fuadah Johari, 'Keberkesanan Zakat dalam Mengatasi Masalah Kemiskinan di Negeri Melaka,' (Disertasi Sarjana, Jabatan Syariah dan Ekonomi, Akademi Pengajian Islam, Universiti Malaya, Kuala Lumpur, 2004). 
perniagaan kecil oleh penerima zakat adalah melihat dari segi faktor-faktor demografi (umur, jantina, taraf pendidikan, saiz keluarga), jenis bantuan, jumlah bantuan, aspek latihan, kerjasama agensi, pemantauan dan pengurusan institusi zakat. ${ }^{26}$

Kajian yang dilakukan oleh Supardi juga telah menunjukkan penemuan yang sama yang mana kajian tersebut telah dilakukan terhadap penerima bantuan zakat yang menjalankan perniagaan secara kecil-kecilan menerusi Program Komuniti Pembangunan Ekonomi (Community Economic Development (CED) di Semarang, Indonesia. ${ }^{27}$ Hasil kajian mendapati bahawa bantuan modal perniagaan berkenaan terlalu kecil jumlahnya dan tidak berupaya mengeluarkan mereka dari kemiskinan (diukur daripada jumlah peningkatan pendapatan) malahan program ini bersifat konservatif yang tidak berupaya meningkatkan kemajuan diri dalam aspek sosial dan political empowerment. Kajian mendapati bahawa kegagalan bantuan ini mencapai matlamat adalah didorong oleh faktor kekurangan bimbingan, latihan, pemantauan dan pengurusan badan yang menguruskan bantuan berkenaan, di samping sikap peserta bantuan yang tidak berdisiplin dan menyalahgunakan bantuan untuk tujuan lain.

Menerusi analisis perbandingan pemberian bantuan modal zakat berbanding bantuan yang diberikan oleh Amanah Ikhtiar Malaysia (AIM) dan Yayasan TEKUN Nasional (TEKUN), didapati bahawa perbezaan paling ketara adalah dari aspek pemantauan yang mana bagi bantuan modal zakat tidak dilakukan pemantauan secara berkala dan sistematik. ${ }^{28}$ Ia dianggap sebagai bantuan berciri ihsan yang menjadi hak golongan fakir miskin. Berjaya atau gagal tidak menjadi persoalan penting. Maka, kemungkinan pada akhirnya penerima bantuan mempunyai motivasi yang rendah, tiada komitmen dan berakhir dengan kegagalan. Kesimpulannya, berdasarkan pandangan dan hasil kajian di atas didapati antara ciri dan faktor penting yang mempengaruhi kejayaan sesuatu perusahaan atau perniagaan yang dijalankan adalah faktor dan ciri keperibadiannya (faktor dalaman) dan dibantu dengan faktor luaran lainnya.

26 Noor Ghani Md. Nor, Abd. Razak \& Mohd Ali Mohd Nor, 'The Contribution of Zakat as An Income Creating Asset in Selangor and Wilayah Persekutuan, Malaysia,' Jurnal Ekonomi Malaysia, vol. 36 (2002): 69-80.

27 Supardi, 'Zakat Organization and Poverty Alleviation; A Macro Social Work and Community Development Perspectives,' (Master Dissertation, School of Graduate Studies, State Islamic University Sunan Kalijaga, Yogyakarta, 2005).

28 Rosbi Abd Rahman, Sanep Ahmad \& Hairunnizam Wahid, 'Pelaksanaan Bantuan Modal Zakat: Analisis Perbandingan,' (Kertas Kerja, Seminar Kebangsaan Ekonomi Malaysia IV, Fakulti Ekonomi dan Perniagaan, Universiti Kebangsaan Malaysia, Port Dickson, 20-22 Ogos 2008). 
Pengukuran Kejayaan Bantuan Modal Perniagaan Usahawan Asnaf dalam Konteks Pencapaian Maqāșid al-Sharī'ah: Kajian di Daerah Kuala Terengganu dan Kuala Nerus, Terengganu

\section{Konsep Maqūạsid al-Sharī'ah}

Maqāṣid merupakan bentuk plural (jama') dari maqsud yang berasal daripada kata qasada yang bermaksud menuju, bertujuan, berkeinginan dan kesengajaan. ${ }^{29}$ Kata maqșud-maqāssid dapat diertikan sebagai tujuan atau beberapa tujuan. Sedangkan al-Syari'ah berasal daripada kata syara'a yang bermaksud jalan menuju sumber air sebagai sumber kehidupan..$^{30}$ Oleh itu, secara terminologi maquașid al-sharī'ah boleh diertikan sebagai tujuan-tujuan ajaran Islam atau dapat juga difahami sebagai tujuan-tujuan pembuat syariat (Allah SWT) dalam menggariskan ajaran atau syari'at Islam. Tidak dapat dinafikan bahawa Syatibi adalah pengasas ilmu maqāșid kerana ia buat pertama kalinya menyusun maqāșid al-sharī'ah secara sistematik dalam kitabnya almuwafaqat fi usul al-syari'ah sehingga wajar disebut sebagai perintis maqāṣid al-sharì'ah. ${ }^{31}$

Maqāṣid al-sharī'ah pula adalah objektif utama Syariah iaitu memelihara agama, nyawa, akal, keturunan dan harta untuk kebajikan manusia. ${ }^{32}$ Maqāṣid al-shar'`ah merangkumi seluruh aspek kehidupan iaitu sosioekonomi serta pembangunan manusia yang mencakupi aspek pendidikan dan kekeluargaan yang mana ia adalah kerangka lengkap untuk pembangunan negara Islam. ${ }^{33}$ Tahap kepentingan manusia berbeza berdasarkan keperluan diri, sosioekonomi, latar belakang pendidikan dan sebagainya. ${ }^{34}$ Syariat Islam bersifat dinamis dan fleksibel menyusun objektif syariah selari dengan keperluan dan kepentingan manusia sejagat. Berdasarkan kepada perspektif syarak, maslahah tahap kepentingan yang perlu dijaga dikategorikan kepada tiga bahagian iaitu al-

29 Wehr, Hans, A Dictionary of Modern Written Arabic (London: McDonald \& Evan Ltd., 1980).

30 Muḥammad Ibn Aḥmad Ibn Muhammad Ibn Aḥmad Ibn Rushd al-Qurțūbī, alJāmi ' li Aḥkām al-Qur'ān, vol. 6 (Bayrūt: Dār al-Kutub al-'Ilmiyyah, 1996), 137.

31 Hasbullah Mat Daud, 'Teori Maqasid al-Syari'ah: Kajian Perbandingan Antara Pemikiran al-Shatibi dan 'Izz al-Dīn Ibn 'Abd al-Salām' (Disertasi Sarjana, Jabatan Fiqh dan Usul, Akademi Pengajian Islam, Universiti Malaya, Kuala Lumpur, 2011).

32 Al-Raysun̄̄, Aḥmad, Nazariyyat al-Maqāṣid 'ind al-Imām al-Shātibī (Qāhirah: Dār al-Kalimah, 2015), 121-122.

33 M. Umer Chapra, The Islamic Vision of Development in the Light of the Maqasid al-Syari'ah (Jeddah, Kingdom of Saudi Arabia: Islamic Research and Training Institute, Islamic Development Bank, 2008), 10.

34 Al-Shātịī̄, Abū Isḥ̄ạ Ibrahim bin Mūsā Ibn Muḥammad al-Lakhmī, al-Muwāfaqāt fì Ușūl al-Sharī'ah, vol. 1-2 (Bayrūt: Dār al-Kutub al-'Ilmiyyah, 2001), 3-5. 
Daruriyyat, al-Hajiyyat dan al-Tahsiniyyat ${ }^{35}$, sepertimana yang disepakati oleh ulama' seperti Imam al-Haramayn, al-Ghazali, 'Izz al-Din 'Abd al-Salam, al-Qarafi, Ibn Taymiyyah dan Ibn Qayyim. Kesejahteraan dan kebahagiaan seseorang individu dan masyarakat akan terjamin seandainya ketiga-tiga maslahah ini dapat dipenuhi dengan cara yang seimbang. Penetapan konsep maslahah ini dalam hidup bermasyarakat secara terang-terangan telah mendahului konsep penjagaan hak asasi manusia yang hanya timbul di dunia Barat dalam konteks zaman moden ini, akibat daripada kesedaran manusia terhadap kemusnahan yang berlaku kerana Perang Dunia Pertama dan Perang Dunia Kedua.

Kajian berkaitan program pembangunan asnaf banyak tertumpu di beberapa negeri sahaja termasuklah negeri Selangor dan Pulau Pinang yang merupakan negeri yang telah mengkorporatkan aspek kutipan dan agihan zakat kepada asnaf. Terdapat kajian yang melihat kepada beberapa hambatan yang boleh menjejaskan kejayaan para peniaga yang menerima bantuan modal zakat ${ }^{36}$ termasuklah tiada pendidikan yang tinggi yang menyumbang kepada kurangnya bakat usahawan, kurang motivasi diri usahawan dan idea perniagaan serta sikap mengambil ringan terhadap modal yang dibiayai daripada dana zakat. Terdapat kajian berkenaan kejayaan maqāṣid al-sharī'ah dalam kalangan usahawan ${ }^{37}$ yang hanya mengukur kejayaan pencapaian maqūșid al-sharì'ah semata-mata tanpa menganalisis dengan lebih lanjut faktor penentu kejayaan kepada pencapaian maqūșid al-sharī'ah.

\section{METODOLOGI KAJIAN}

Kajian ini menggunakan kaedah kualitatif dan kuantitatif. Populasi kajian ini terdiri daripada golongan usahawan asnaf yang menjalankan perniagaan dengan menggunakan bantuan modal perniagaan di negeri Terengganu. Seramai 140 orang responden usahawan asnaf dipilih berdasarkan senarai nama penerima bantuan modal perniagaan daripada MAIDAM sebagai responden kajian ini yang mewakili hampir 30 peratus daripada jumlah keseluruhan responden.

35 Al-Shātịīī, Abū Ishāā Ibrahim bin Mūsā Ibn Muhammad al-Lakhmī, al-Muwāfaqāt fì Ușūl al-Sharī'ah, 7.

36 Azman, A.R, Mohamad Yazis, Mahdhir, Mohammad Noorizzudin \& Ahmad Anis, 'Keberkesanan Program Usahawan Asnaf Oleh Institusi Zakat dalam Menginterpretasikan Keharmonian Ummah,' (International Conference on Arabic Studies and Islamic Civilization iCasic, Kuala Lumpur, 4-5 Mac 2014), 507.

37 Rosbi Abd Rahman \& Sanep Ahmad, 'Strategi Pembangunan Keusahawanan Asnaf Fakir dan Miskin melalui Agihan Bantuan Modal Zakat,' Jurnal Pengurusan, vol. 33 (2011): 37-44. 
Pengukuran Kejayaan Bantuan Modal Perniagaan Usahawan Asnaf dalam Konteks Pencapaian Maqāṣid al-Sharī‘ah: Kajian di Daerah Kuala Terengganu dan Kuala Nerus, Terengganu

Pemilihan responden dijalankan di seluruh daerah Kuala Terengganu dan Kuala Nerus, Terengganu. Kedua-dua daerah ini dipilih untuk mendapatkan hasil kajian yang seimbang antara kawasan bandar yang diwakili daerah Kuala Terengganu dan kawasan luar bandar yang diwakili oleh daerah Kuala Nerus. Kaedah temubual ini penting bertujuan mendapatkan maklumat dengan lebih terperinci disamping data yang melibatkan subjek utama kajian iaitu mendapatkan maklumat kejayaan perniagaan.

Soal selidik yang berkaitan faktor-faktor berkenaan (selain demografi dan latar belakang perniagaan) tersebut akan diukur dengan menggunakan skala likert berikut: Nilai 1 adalah untuk pernyataan 'sangat tidak setuju' manakala, 5 adalah bagi pernyataan 'sangat setuju'. Kajian ini akan menggabungkan ciri-ciri demografi dan maklumat perniagaan yang merangkumi faktor umur, taraf pendidikan, tahap kesihatan, tempoh berniaga, modal yang mencukupi, pemasaran, tiada persaingan, lokasi/premis perniagaan dan kos operasi yang rendah. Manakala bagi soal selidik yang berkaitan prinsip maqāșid al-sharī'ah pula, diukur keberkesanan tersebut, dinilai dan dikodkan dalam bentuk Change Assessment and Scoring Tool (CAST) seperti yang telah dilakukan oleh pengkaji sebelum ini ${ }^{38}$. Menerusi kaedah CAST ini ukuran keberkesanan diperoleh apabila melihat kepada perubahan yang berlaku kepada responden apabila sesuatu program dilaksanakan. Perubahan ini akan diukur dengan skala 5 skala iaitu perubahan daripada yang paling positif kepada perubahan yang paling negatif.

Model asal CAST ini melihat kepada empat aspek/indikator utama untuk mengukur perubahan yang dicapai oleh responden iaitu dari segi livehood, resources/services, knowledge dan human right. Namun, bagi tujuan kajian keberkesanan bantuan modal zakat ini, pengubahsuai dan menggunakan 5 aspek/indikator sebagai ukuran keberkesanan bantuan modal perniagaan kepada golongan usahawan asnaf menggunakan pendekatan prinsip maqāșid al-sharī'ah. Prinsip maqāșid al-sharī'ah meletakkan lima keperluan penting yang perlu dipenuhi oleh Muslim iaitu keperluan agama, nyawa, akal dan fikiran, maruah dan keturunan serta harta. Menerusi kaedah CAST ini setiap keperluan yang digariskan akan dinilai sama ada memberikan perubahan positif atau sebaliknya kepada golongan usahawan asnaf. Pengukuran kejayaan golongan usahawan asnaf dalam perniagaan akan diukur dan dikategorikan kepada tiga keadaan pencapaian maqāșid al-sharī'ah sama ada kategori berjaya (nilai min: 4.25-5.00; markah 85\%), sederhana (nilai min: 3.50-4.24; markah $70 \%$ - 84\%) dan kurang berjaya (nilai min: bawah 3.49; markah

38 Rosbi Abd Rahman \& Sanep Ahmad, 'Strategi Pembangunan Keusahawanan Asnaf Fakir dan Miskin melalui Agihan Bantuan Modal Zakat,' 37-44. 
kurang 70\%) dengan merujuk kepada kaedah pengukuran kejayaan usahawan asnaf dalam aspek maqāșid al-sharī'ah oleh kajian sebelum ini ${ }^{39}$. Justeru, skor min ini amat sesuai digunakan dalam kajian bagi merumuskan sejauh mana keberkesanan program berkenaan dapat mengubah keadaan hidup responden berkenaan ke arah memenuhi keperluan hidup yang telah digariskan dalam kelima-lima prinsip maqāșid al-sharī'ah.

Spesifikasi Model \& Kaedah Analisis Data: Kajian ini akan menggunakan pelbagai kaedah analisis data termasuklah analisis secara diskriptif serta analisis faktor dalam menganalisis respons usahawan yang menerima bantuan modal dari MAIDAM. Ujian regresi logistik juga akan dilakukan untuk menguji apakah faktor penentu berkebarangkalian mempengaruhi kejayaan usahawan tersebut sama ada daripada aspek pendapatan mahu pun maqāșid al-sharī'ah sebagai pemboleh ubah bersandar. Maksud berjaya daripada aspek pendapatan adalah pengukuran keberkesanan bantuan yang disalurkan kepada usahawan asnaf berjaya atau sebaliknya berdasarkan hasil pendapatan yang diterima selepas menerima bantuan modal perniagaan berbanding sebelum menerima bantuan modal perniagaan. Maksud berjaya daripada aspek maqāșid al-sharī'ah pula adalah pengukuran keberkesanan bantuan yang disalurkan kepada usahawan tersebut berjaya atau sebaliknya, membantu mereka mencapai lima keperluan maqāṣid al-sharī'ah, iaitu menjaga kesucian agama (ad-Din), menjamin keselamatan nyawa (al-Nafs), menjamin kemuliaan akal dan fikiran (al-Aqal), menjamin kehormatan dan maruah diri (al-Nasb) dan menjamin keselamatan harta (al-Mal).

Model dibentuk dengan pemboleh ubah bersandar berbentuk binari iaitu sama ada berjaya dalam kedua-dua aspek tersebut atau sebaliknya. Model yang dianggarkan secara umumnya adalah seperti berikut:

$$
\mathrm{P}_{\mathrm{i}}=\mathrm{E}(\mathrm{Y}=1 \mid \mathrm{X})=1 /\left(1+\mathrm{e}^{-\mathrm{Z}}\right)
$$

Di mana,

$\mathrm{P}_{\mathrm{i}} \quad$ Adalah kebarangkalian bagi responden berjaya

$\mathrm{Y}=1 \quad$ Adalah responden yang berjaya sama dari segi aspek pendapatan atau maqāșid al-sharī'ah

$\mathrm{Y}=0 \quad$ Adalah bagi responden yang tidak berjaya.

Berdasarkan persamaan (1), kajian ini akan menguji beberapa pemboleh ubah yang dijangka mempengaruhi $\mathrm{P}_{\mathrm{i}}$ seperti berikut:

39 Rosbi Abd Rahman \& Sanep Ahmad, 'Strategi Pembangunan Keusahawanan Asnaf Fakir dan Miskin melalui Agihan Bantuan Modal Zakat,' 37-44. 
Pengukuran Kejayaan Bantuan Modal Perniagaan Usahawan Asnaf dalam Konteks Pencapaian Maqāșid al-Sharī'ah: Kajian di Daerah Kuala Terengganu dan Kuala Nerus, Terengganu

$$
Z_{i}=\beta_{0}+\beta_{1} X_{1}+\beta_{2} X_{2}+\beta_{3} X_{3}+\ldots+\beta_{i} X_{i}
$$

Di mana,

$\mathrm{Z}$ Adalah satu fungsi $\mathrm{f}(\mathrm{X})$ dengan $\mathrm{X}$ adalah pemboleh ubah bersandar yang dijangka mempengaruhi pemboleh ubah bebas

$\mathrm{Z}_{\mathrm{i}} \quad$ Merupakan Model I dimana pengukuran kejayaan usahawan asnaf daripada aspek pendapatan iaitu bernilai 0 jika hasil pendapatan selepas menerima bantuan modal perniagaan sama atau kurang daripada hasil pendapatan sebelum menerima modal manakala, bernilai 1 jika hasil pendapatan selepas menerima bantuan modal perniagaan lebih daripada hasil pendapatan sebelum menerima modal

$\mathrm{Z}_{\mathrm{ii}} \quad$ Merupakan Model II dimana pengukuran kejayaan usahawan asnaf daripada aspek maqūṣsid al-sharī'ah iaitu bernilai 0 jika tidak berjaya mencapai lima keperluan maqāșid al-sharī $a h$ dan bernilai 1 jika berjaya mencapai lima keperluan maqāssid al-sharī'ah.

$\mathrm{X}_{1} \quad$ Taraf pendidikan (pembolehubah dami); nilai 0 untuk tahap pendidikan SPM ke bawah dan bernilai 1 adalah sebaliknya

$\mathrm{X}_{2}$ Tahap kesihatan (pembolehubah dami); bernilai 0 jika responden berpendapat beliau tidak sihat dan bernilai 1 adalah sebaliknya.

$\mathrm{X}_{3} \quad$ Tempoh berniaga (pembolehubah dami); bernilai 0 jika tempoh kurang daripada 4 tahun dan bernilai ladalah sebaliknya

$\mathrm{X}_{4} \quad$ Modal perniagaan mencukupi (Skala likert 1 hingga 5)

$\mathrm{X}_{5} \quad$ Pemasaran (Skala likert 1 hingga 5)

$\mathrm{X}_{6} \quad$ Tiada persaingan (Skala likert 1 hingga 5)

$\mathrm{X}_{7} \quad$ Lokasi/Premis perniagaan (Skala likert 1 hingga 5)

$\mathrm{X}_{8} \quad$ Kos operasi yang rendah (Skala likert 1 hingga 5)

\section{HASIL KAJIAN}

Latar belakang responden: Bagi menilai keberkesanan bantuan modal perniagaan ini, seramai 140 penerima bantuan modal perniagaan di daerah Kuala Terengganu dan Kuala Nerus telah dikaji berdasarkan senarai bantuan modal perniagaan yang yang disediakan oleh Majlis Agama Islam dan Adat Melayu (MAIDAM). Jadual berikut menunjukkan maklumat latar belakang responden yang akan merangkumi maklumat seperti umur, status perkahwinan, taraf pendidikan, tahap kesihatan dan jumlah tanggungan responden. 
Jadual 1: Ringkasan Profil Responden

\begin{tabular}{llcc}
\hline \multicolumn{1}{c}{ Latar Belakang Responden } & $\begin{array}{c}\text { Bilangan } \\
\text { Responden }\end{array}$ & $\begin{array}{c}\text { Peratusan } \\
(\%)\end{array}$ \\
\hline \multirow{2}{*}{ Umur } & Kurang daripada 34 tahun & 39 & 27.9 \\
& Lebih daripada 35 tahun & 101 & 72.1 \\
Status & Bujang & 8 & 5.7 \\
Perkahwinan & Berkahwin & 98 & 70.0 \\
Taraf & Janda/Ibu tunggal & 5 & 3.6 \\
Pendidikan & SPM ke bawah & 29 & 20.7 \\
Tahap & SPM ke atas & 59 & 42.1 \\
Kesihatan & Kurang sihat & 81 & 57.9 \\
Jumlah & Sihat & 44 & 31.4 \\
Tanggungan & 1 hingga 3 orang & 96 & 68.6 \\
Keluarga & 9 hingga 8 orang & 84 & 60.0 \\
& Lebih daripada 12 orang & 49 & 35.0 \\
\hline
\end{tabular}

Sumber: Soal Selidik 2016

\section{Ringkasan Jumlah Pendapatan dari Hasil Perniagaan}

Jadual 2 di bawah menunjukkanjumlah pendapatan bulanan golongan usahawan asnaf. Setelah menerima bantuan modal perniagaan, pendapatan golongan usahawan ini menunjukkan perubahan yang positif dan membanggakan. Di sini, terbukti dengan keupayaan mereka mengubah hidup yang lebih baik yang mana bantuan modal perniagaan mampu meningkatkan pendapatan bulanan mereka. 
Pengukuran Kejayaan Bantuan Modal Perniagaan Usahawan Asnaf dalam Konteks Pencapaian Maqāșid al-Sharī'ah: Kajian di Daerah Kuala Terengganu dan Kuala Nerus, Terengganu

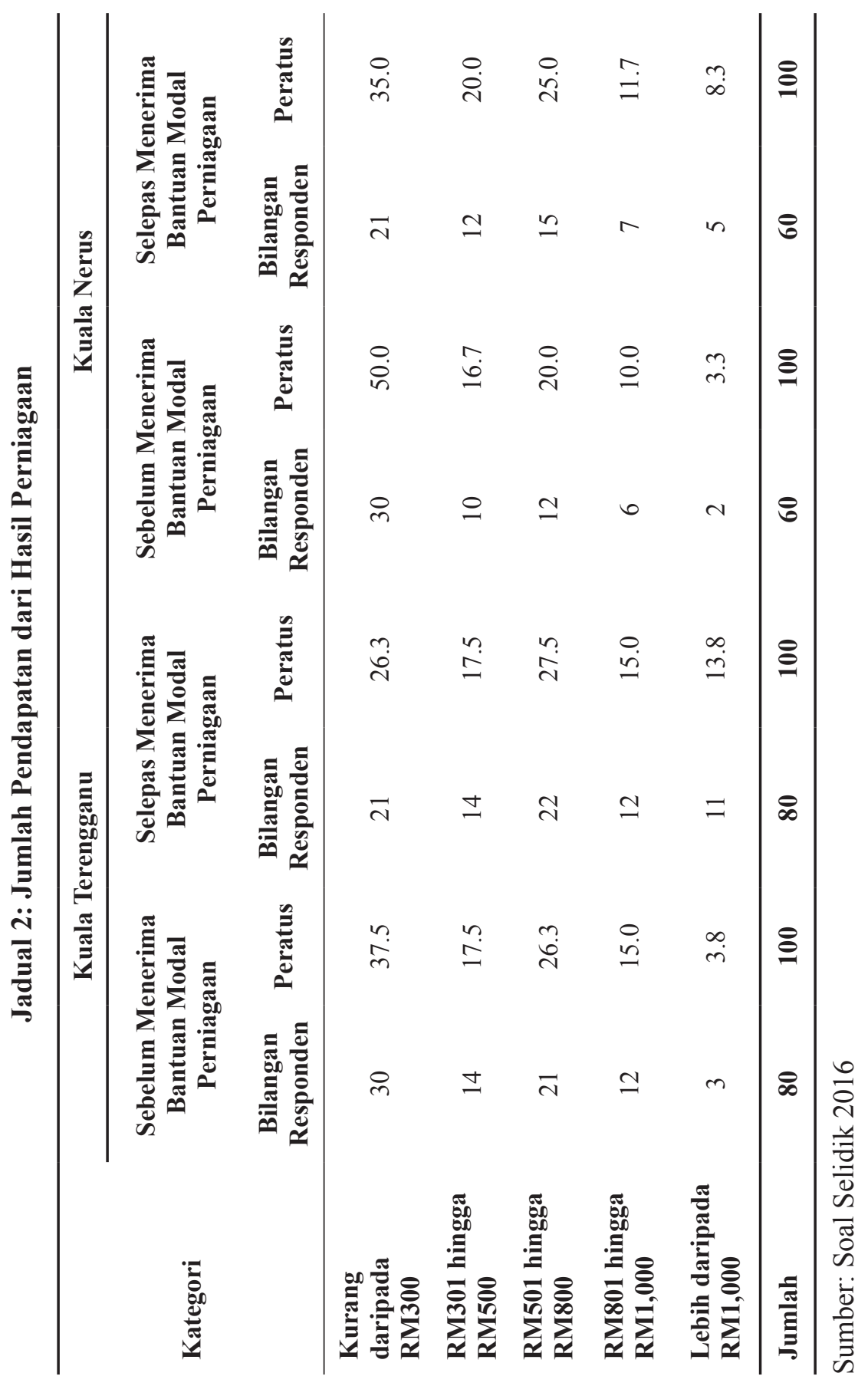




\section{Ringkasan Pencapaian Setiap Individu Berdasarkan Kaedah Penilaian} Keberkesanan Bantuan Modal Perniagaan Berasaskan Maqūṣsid al-Sharī‘ ah

Jadual 3 pula, menunjukkan ringkasan bagi setiap responden terhadap kelimalima keperluan yang dikaji. Pencapaian ini dinilai dengan mengambil kira pandangan setiap responden pada tahap mana pencapaian mereka. Didapati secara keseluruhan bagi kelima-lima keperluan, majoriti responden iaitu seramai 52 orang $(37.1 \%)$ berada pada kategori berjaya berbanding seramai 80 orang $(57.1 \%)$ pada tahap sederhana dan 8 orang $(5.7 \%)$ tidak berjaya. Sekiranya penilaian dibuat mengikut setiap prinsip maqāșid al-sharī'ah, maka didapati bahawa majoriti responden menilainya lebih kepada tahap kurang berjaya berbanding tahap berjaya dan sederhana berjaya.

\section{Jadual 3: Ringkasan Pencapaian Setiap Individu Berdasarkan Kaedah Penilaian Keberkesanan Bantuan Modal Perniagaan}

\begin{tabular}{|c|c|c|c|c|}
\hline \multirow{2}{*}{$\begin{array}{l}\text { Prinsip Maqāṣid al- } \\
\text { Shari'‘ah }\end{array}$} & \multicolumn{3}{|c|}{ Bilangan Responden Mengikut Kategori } & \multirow{2}{*}{$\begin{array}{l}\text { Purata } \\
\text { Skor }\end{array}$} \\
\hline & $\begin{array}{c}\text { Berjaya } \\
(4.25-5.00)(\%)\end{array}$ & $\begin{array}{c}\text { Sederhana } \\
(3.50-4.24)(\%)\end{array}$ & $\begin{array}{c}\text { Kurang berjaya } \\
(1.00-3.49)(\%)\end{array}$ & \\
\hline $\begin{array}{l}\text { Menjaga Agama } \\
\text { (al-Din) }\end{array}$ & $\begin{array}{c}82 \\
(58.6)\end{array}$ & $\begin{array}{c}45 \\
(32.1)\end{array}$ & $\begin{array}{c}13 \\
(9.3)\end{array}$ & 2.49 \\
\hline $\begin{array}{l}\text { Menjaga Nyawa } \\
(a l-N a f s)\end{array}$ & $\begin{array}{c}54 \\
(38.6)\end{array}$ & $\begin{array}{c}64 \\
(45.7)\end{array}$ & $\begin{array}{c}22 \\
(15.7)\end{array}$ & 2.23 \\
\hline $\begin{array}{l}\text { Menjaga Akal dan } \\
\text { Fikiran }\left(a l^{-} A q l\right)\end{array}$ & $\begin{array}{c}61 \\
(43.6)\end{array}$ & $\begin{array}{c}62 \\
(44.3)\end{array}$ & $\begin{array}{c}17 \\
(12.1)\end{array}$ & 2.31 \\
\hline $\begin{array}{l}\text { Menjaga Maruah } \\
\text { dan Keturunan } \\
\text { (al-Nasl) }\end{array}$ & $\begin{array}{c}59 \\
(42.1)\end{array}$ & $\begin{array}{c}71 \\
(50.7)\end{array}$ & $\begin{array}{c}10 \\
(7.1)\end{array}$ & 2.35 \\
\hline $\begin{array}{l}\text { Menjaga Harta } \\
(\text { al-Mal) }\end{array}$ & $\begin{array}{c}41 \\
(29.3)\end{array}$ & $\begin{array}{c}84 \\
(60.0)\end{array}$ & $\begin{array}{c}15 \\
(10.7)\end{array}$ & 2.19 \\
\hline $\begin{array}{l}\text { Purata Bagi } 5 \\
\text { Prinsip Maqāṣid } \\
\text { al-Sharī'ah }\end{array}$ & $\begin{array}{c}52 \\
(37.1)\end{array}$ & $\begin{array}{c}80 \\
(57.1)\end{array}$ & $\begin{array}{c}8 \\
(5.7)\end{array}$ & 2.31 \\
\hline
\end{tabular}

Sumber: Soal Selidik 2016 
Pengukuran Kejayaan Bantuan Modal Perniagaan Usahawan Asnaf dalam Konteks Pencapaian Maqāṣid al-Sharī‘ah: Kajian di Daerah Kuala Terengganu dan Kuala Nerus, Terengganu

\section{Keberkesanan Bantuan Modal Perniagaan Dari Segi Aspek Pencapaian Kejayaan Perniagaan Berasaskan Pendapatan dan Maqāṣid al-Sharī'ah}

Analisis akan dilakukan bagi melihat perbandingan keberkesanan bantuan modal perniagaan terhadap aspek pencapaian kejayaan perniagaan berasaskan pendapatan dengan maqāșid al-sharī'ah serta hubung kait antara pencapaian kejayaan perniagaan berasaskan pendapatan dan maqāșid al-sharī'ah. Analisis khi-kuasa dua akan digunakan bagi melihat hubungan kait antara dua pemboleh ubah tersebut.

\section{Perbandingan antara Keberkesanan Bantuan Modal Perniagaan Dari Segi Aspek Pencapaian Kejayaan Perniagaan Berasaskan Pendapatan dengan Maqāṣid al-Sharī'ah}

Berdasarkan Jadual 4, bagi daerah Kuala Terengganu didapati seramai 24 responden $(30.0 \%)$ berjaya berasaskan pendapatan berbanding 28 responden (35.0\%) yang berjaya berasaskan maqūṣid al-sharī' $a h$. Namun begitu, seramai 56 responden $(70.0 \%)$ pula yang tidak berjaya berasaskan pendapatan terhadap keberkesanan bantuan modal perniagaan yang yang diterima berbanding 52 responden $(65.0 \%)$ yang tidak berjaya berasaskan maqāsid al-sharī'ah. Maka, jumlah ini harus diberi perhatian memandangkan peratusan yang tidak berjaya lebih tinggi berbanding yang berjaya. Manakala, bagi daerah Kuala Nerus didapati seramai 16 responden $(26.7 \%)$ berjaya berasaskan pendapatan berbanding 24 responden (40.0\%) yang berjaya berasaskan maqāșid alsharì' $a$ h. Namun begitu, seramai 44 responden $(73.3 \%)$ pula yang tidak berjaya berasaskan pendapatan terhadap keberkesanan bantuan modal perniagaan yang yang diterima berbanding 36 responden (60.0\%) yang tidak berjaya berasaskan maqāṣid al-sharī'ah. Maka, jumlah ini harus diberi perhatian memandangkan peratusan yang tidak berjaya lebih tinggi berbanding yang berjaya. 
Jurnal Syariah, Jil. 27, Bil. 2 (2019) 201-232

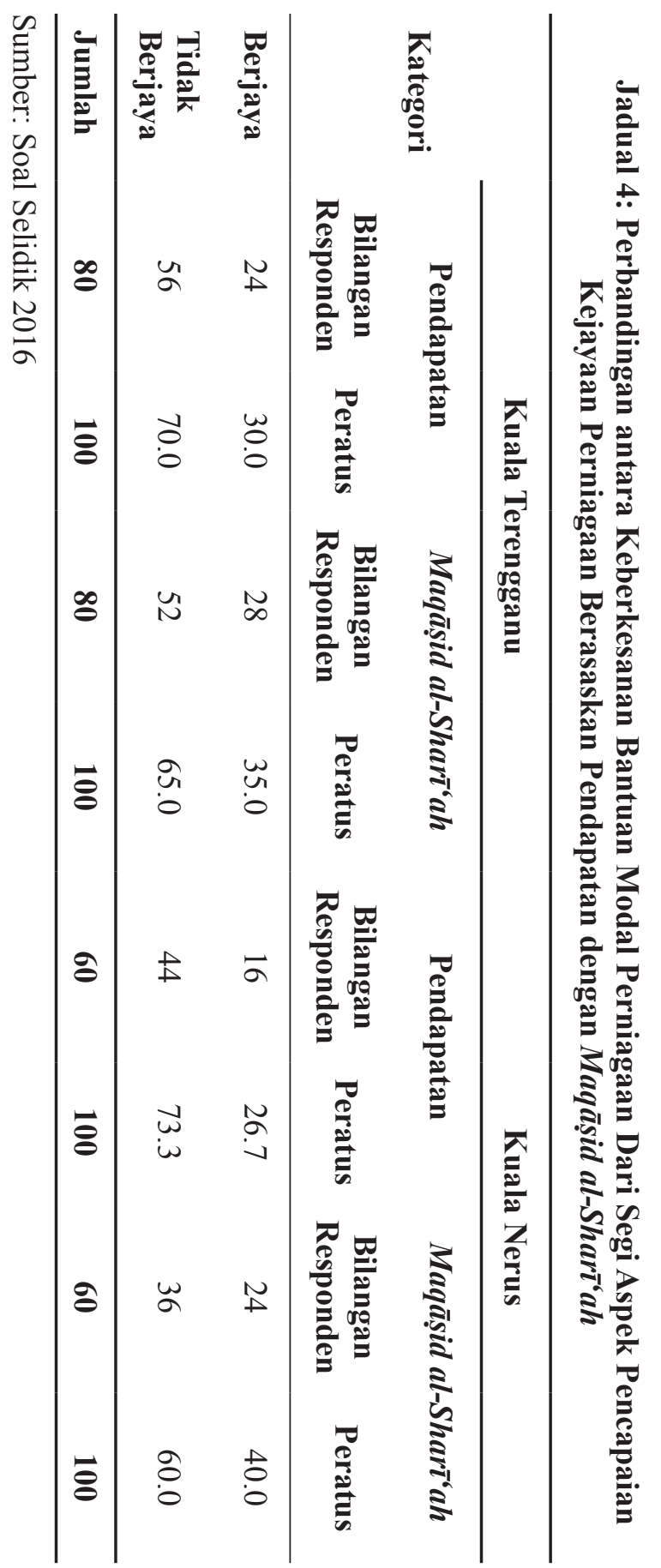


Pengukuran Kejayaan Bantuan Modal Perniagaan Usahawan Asnaf dalam Konteks Pencapaian Maqāṣid al-Sharī'ah: Kajian di Daerah Kuala Terengganu dan Kuala Nerus, Terengganu

\section{Hubungan antara Keberkesanan Bantuan Modal Perniagaan Dari Segi Aspek Pencapaian Kejayaan Perniagaan Berasaskan Pendapatan dengan Maqāșid al-Sharī'ah}

Berdasarkan Jadual 5, bagi daerah Kuala Terengganu seramai 7 responden $(8.75 \%)$ berjaya berasaskan pendapatan dan maquassid al-sharī'ah. Seramai 17 responden (21.25\%) yang tidak berjaya berasaskan maqāșid al-sharī'ah, tetapi berjaya berasaskan pendapatan. Bagi responden yang tidak berjaya berasaskan pendapatan adalah 56 responden (70.0\%), majoriti 35 responden (43.75\%) tidak berjaya berasaskan maqāșid al-sharī 'ah dan tidak berjaya juga berasaskan pendapatan terhadap keberkesanan bantuan modal perniagaan yang diterima. Manakala, seramai 21 responden $(26.25 \%)$ berjaya berasaskan maqāssid al-sharī'ah, tetapi tidak berjaya berasaskan pendapatan. Hal ini bermakna, walaupun majoriti penerima bantuan modal perniagaan tidak berjaya berasaskan pendapatan iaitu seramai 56 responden $(70.0 \%)$ berbanding 24 responden (30.0\%) yang berjaya berasaskan pendapatan, namun, 28 responden $(35.0 \%)$ berjaya berasaskan maqāșid al-sharī'ah terhadap keberkesanan bantuan modal perniagaan yang diterima berbanding 52 responden $(65.0 \%)$ tidak berjaya berasaskan maqāșid al-sharī'ah. Hal ini walaupun seramai 35 responden (43.75\%) tidak berjaya untuk kedua-dua iaitu berasaskan pendapatan dan maqāṣid al-sharí'ah dan dikhuatiri keputusan adalah kemungkinan tidak tepat, namun seramai 7 responden (8.75\%) adalah berjaya untuk berasaskan pendapatan dan maqāssid al-sharī'ah. Manakala, bagi daerah Kuala Nerus seramai 5 responden $(8.33 \%)$ berjaya berasaskan pendapatan dan maqāșid al-sharī'ah. Seramai 11 responden (18.33\%) yang tidak berjaya berasaskan maqāssid al-sharī'ah, tetapi berjaya berasaskan pendapatan. Bagi responden yang tidak berjaya berasaskan pendapatan adalah 44 responden $(73.33 \%)$, majoriti 25 responden (41.67\%) tidak berjaya berasaskan maqạsid al-sharì'ah dan tidak berjaya juga berasaskan pendapatan terhadap keberkesanan bantuan modal perniagaan yang diterima. Manakala, seramai 19 responden $(31.67 \%)$ berjaya berasaskan maqāssid al-sharī'ah, tetapi tidak berjaya berasaskan pendapatan. Hal ini bermakna, walaupun majoriti penerima bantuan modal perniagaan tidak berjaya berasaskan pendapatan iaitu seramai 44 responden $(73.33 \%)$ berbanding 16 responden $(26.67 \%)$ yang berjaya berasaskan pendapatan, namun, 24 responden $(40.0 \%)$ berjaya berasaskan maqāșid alshari'ah terhadap keberkesanan bantuan modal perniagaan yang diterima berbanding 36 responden $(60.0 \%)$ tidak berjaya berasaskan maqāssid alsharí'ah. Hal ini walaupun seramai 25 responden (41.67\%) tidak berjaya untuk kedua-dua iaitu berasaskan pendapatan dan maqāssid al-sharì'ah, namun seramai 5 responden (8.33\%) adalah berjaya untuk berasaskan pendapatan dan maqāșid al-sharī'ah. 


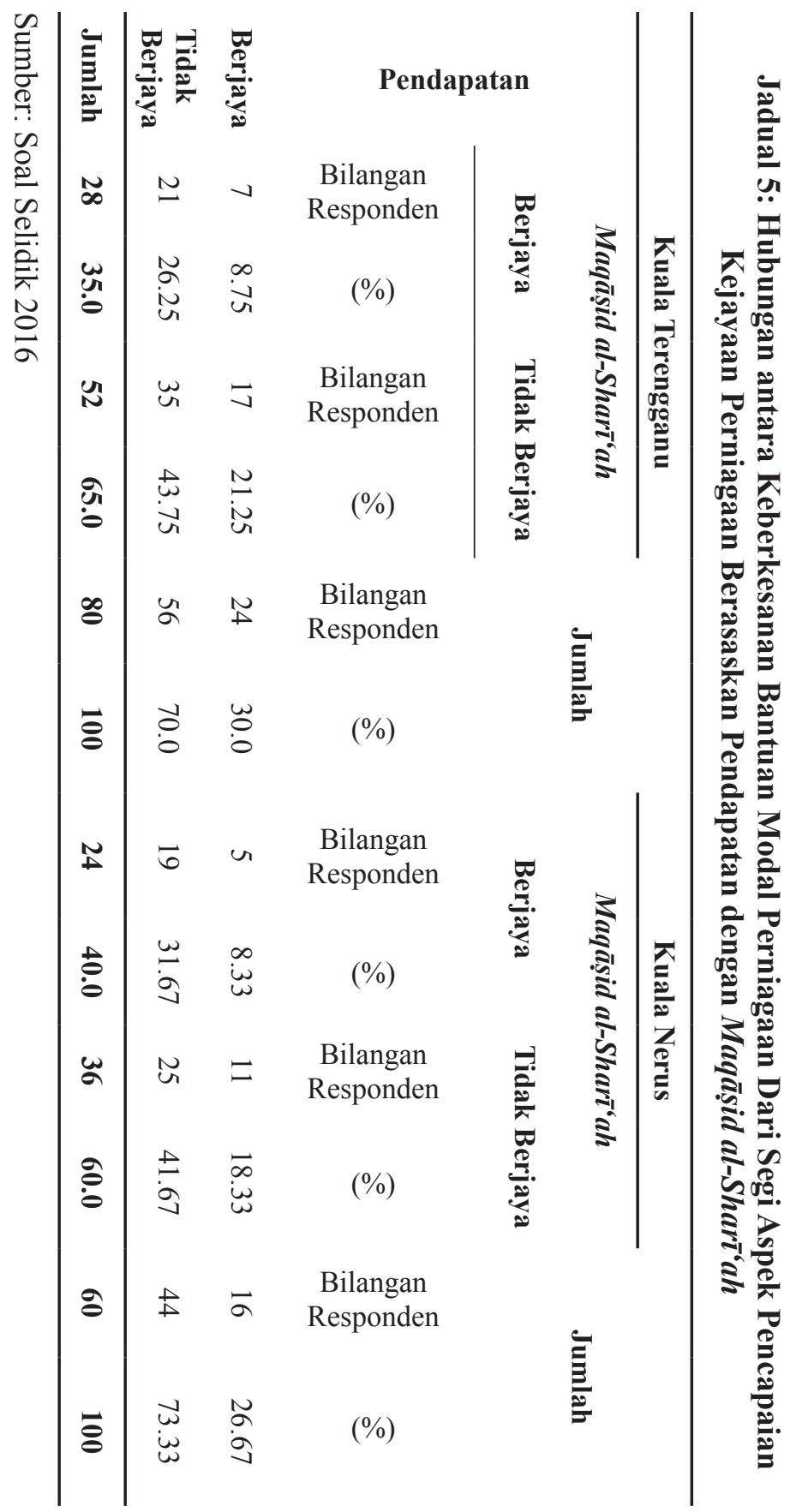


Pengukuran Kejayaan Bantuan Modal Perniagaan Usahawan Asnaf dalam Konteks Pencapaian Maqāșid al-Sharī'ah: Kajian di Daerah Kuala Terengganu dan Kuala Nerus, Terengganu

Ujian Regresi Logistik Dari Segi Aspek Pencapaian Kejayaan Perniagaan Berasaskan Pendapatan (Model I)

Jadual 6: Pengelasan Regresi Logistik ${ }^{a}$ Pencapaian Kejayaan Perniagaan Berasaskan Pendapatan

\begin{tabular}{lccc}
\hline \multicolumn{3}{c}{ Diramalkan } \\
\hline \multirow{2}{*}{ Pemerhatian } & Tidak berjaya & Berjaya \\
& Tidak berjaya & 93 & 7 \\
& Berjaya & 21 & 19 \\
\hline
\end{tabular}

Nota: ${ }^{a}$ nilai batasan: .500

Peratusan betul: Tidak berjaya $=93.0 \%$; Berjaya $=47.5 \%$; Keseluruhan $=$ $80.0 \%$

Jadual 6 menunjukkan jawapan yang diberikan adalah disahkan benar dan amat sesuai untuk dianalisis. Secara keseluruhannya lebih 80.0 peratus disahkan jawapan usahawan asnaf adalah benar daripada yang dikaji. Berdasarkan Jadual 7, kajian di analisis menggunakan analisis regresi logistik. Jika dilihat kepada nilai koefisien ketiga-tiga analisis tersebut, dapat dirumuskan daerah Kuala Terengganu tiada pemboleh ubah yang signifikan. Manakala, daerah Kuala Nerus pula hanya satu pemboleh ubah yang signifikan iaitu modal yang mencukupi. Seterusnya, gabungan dua daerah didapati hanya dua pemboleh ubah yang signifikan iaitu modal yang mencukupi dan lokasi/premis perniagaan. Kesemua pemboleh ubah masing-masing signifikan pada aras keertian 5 peratus. Ujian padanan menggunakan kaedah Hosmer and Lemeshow mencatatkan nilai Chi-Square bagi daerah Kuala Terengganu sebanyak $5.421(\mathrm{sig}=0.712)$, daerah Kuala Nerus $6.600(\mathrm{sig}=0.580)$ dan kajian keseluruhan sebanyak $14.170(\mathrm{sig}=0.077)$, kesemuanya dengan 8 darjah kebebasan. Kedudukan ini menunjukkan bahawa kajian mempunyai padanan yang baik dengan data. Namun begitu, nilai $R^{2}$ pula yang menunjukkan variasi kesemua pemboleh ubah bagi ketiga-tiga tersebut dalam lingkungan sekitar 18.8 peratus hingga 27.0 peratus berasaskan Cox and Snell $\mathrm{R}^{2}$ dan Nagelkerke $\mathrm{R}^{2}$. Ini menunjukkan variasi pemboleh ubah bebas adalah agak bebas menerangkan pemboleh ubah bersandar. 


\section{Jadual 7: Hasil Regresi Pencapaian Kejayaan Perniagaan Berasaskan Pendapatan}

\begin{tabular}{|c|c|c|c|}
\hline Pemboleh ubah & $\begin{array}{l}\text { Nilai Koefisien ( } \beta \text { ) } \\
\text { Kuala Terengganu }\end{array}$ & $\begin{array}{c}\text { Nilai Koefisien ( } \beta \text { ) } \\
\text { Kuala Nerus }\end{array}$ & $\begin{array}{c}\text { Nilai Koefisien }(\beta) \\
\text { Keseluruhan }\end{array}$ \\
\hline Konstan & $\begin{array}{l}-4.801 \\
(2.090) \\
{[5.277]}\end{array}$ & $\begin{array}{c}9.012 \\
(4.497) \\
{[4.017]}\end{array}$ & $\begin{array}{l}-5.484 \\
(1.738) \\
{[9.961]}\end{array}$ \\
\hline Umur & $\begin{array}{c}0.013 \\
(0.690) \\
{[0.000]}\end{array}$ & $\begin{array}{l}-1.392 \\
(1.097) \\
{[1.611]}\end{array}$ & $\begin{array}{l}-0.291 \\
(0.549) \\
{[0.280]}\end{array}$ \\
\hline Pendidikan & $\begin{array}{l}-0.103 \\
(0.585) \\
{[0.031]}\end{array}$ & $\begin{array}{c}0.242 \\
(0.850) \\
{[0.081]}\end{array}$ & $\begin{array}{l}-0.009 \\
(0.465) \\
{[0.000]}\end{array}$ \\
\hline Kesihatan & $\begin{array}{l}0.589 \\
(0.669) \\
{[0.774]}\end{array}$ & $\begin{array}{l}1.020 \\
(0.917) \\
{[1.236]}\end{array}$ & $\begin{array}{c}0.765 \\
(0.526) \\
{[2.116]}\end{array}$ \\
\hline Tempoh berniaga & $\begin{array}{l}1.023 \\
(0.602) \\
{[2.886]}\end{array}$ & $\begin{array}{l}2.403 \\
(1.129) \\
{[4.529]}\end{array}$ & $\begin{array}{l}1.395 \\
(0.505) \\
{[7.643]}\end{array}$ \\
\hline $\begin{array}{l}\text { Modal yang } \\
\text { mencukupi }\end{array}$ & $\begin{array}{l}0.810 \\
(0.371) \\
{[4.761]}\end{array}$ & $\begin{array}{l}-1.809^{*} \\
(0.585) \\
{[9.554]}\end{array}$ & $\begin{array}{c}1.051^{*} \\
(0.293) \\
{[12.849]}\end{array}$ \\
\hline Pemasaran & $\begin{array}{l}-0.077 \\
(0.264) \\
{[0.085]}\end{array}$ & $\begin{array}{l}0.086 \\
(0.493) \\
{[0.031]}\end{array}$ & $\begin{array}{l}-0.075 \\
(0.227) \\
{[0.108]}\end{array}$ \\
\hline Tiada persaingan & $\begin{array}{c}0.369 \\
(0.276) \\
{[1.779]}\end{array}$ & $\begin{array}{l}-0.226 \\
(0.455) \\
{[0.247]}\end{array}$ & $\begin{array}{c}0.213 \\
(0.230) \\
{[0.859]}\end{array}$ \\
\hline $\begin{array}{l}\text { Lokasi/Premis } \\
\text { perniagaan }\end{array}$ & $\begin{array}{c}0.508 \\
(0.250) \\
{[4.122]}\end{array}$ & $\begin{array}{l}-1.166 \\
(0.457) \\
{[6.503]}\end{array}$ & $\begin{array}{l}0.663 * \\
(0.211) \\
{[9.828]}\end{array}$ \\
\hline $\begin{array}{l}\text { Kos operasi yang } \\
\text { rendah }\end{array}$ & $\begin{array}{l}-0.386 \\
(0.306) \\
{[1.595]}\end{array}$ & $\begin{array}{c}0.097 \\
(0.592) \\
{[0.027]}\end{array}$ & $\begin{array}{l}-0.345 \\
(0.254) \\
{[1.844]}\end{array}$ \\
\hline $\begin{array}{l}\text { Hosmer and } \\
\text { Lemeshow }(x) \\
\text { Cox and Snell } \mathbf{R}^{2}\end{array}$ & $5.421^{\text {ns }}$ & $6.600^{\mathrm{ns}}$ & $14.170^{\mathrm{ns}}$ \\
\hline Negelkerke $\mathbf{R}^{2}$ & 0.204 & 0.479 & 0.270 \\
\hline
\end{tabular}

Nota: * signifikan pada aras keertian 5\%

ns tidak signifikan

( ) ralat piawai

[ ] ujian wald

Model regresi : Regresi binomial logistik. Pemboleh ubah

bersandar : Pencapaian kejayaan perniagaan berasaskan pendapatan 
Pengukuran Kejayaan Bantuan Modal Perniagaan Usahawan Asnaf dalam Konteks Pencapaian Maqāṣid al-Sharī‘ah: Kajian di Daerah Kuala Terengganu dan Kuala Nerus, Terengganu

Ujian Regresi Logistik Dari Segi Aspek Pencapaian Kejayaan Perniagaan Berasaskan Maqāṣsid al-Sharī'ah (Model II)

\section{Jadual 8: Pengelasan Regresi Logistik ${ }^{a}$ Pencapaian Kejayaan Perniagaan Berasaskan Maqāṣsid al-Sharī'ah}

\begin{tabular}{lccc}
\hline \multicolumn{3}{c}{ Diramalkan } \\
\hline \multirow{2}{*}{ Pemerhatian } & Tidak Berjaya & Berjaya \\
& Tidak Berjaya & 73 & 14 \\
& Berjaya & 25 & 27 \\
\hline
\end{tabular}

Nota: ${ }^{a}$ nilai batasan: .500

Peratusan betul: Tidak berjaya $=83.9 \%$; Berjaya $=51.9 \%$; Keseluruhan $=71.9 \%$

Jadual 8 menunjukkan jawapan yang diberikan adalah disahkan benar dan amat sesuai untuk dianalisis. Secara keseluruhannya lebih 71.9 peratus disahkan jawapan usahawan asnaf adalah benar daripada yang dikaji. Berdasarkan Jadual 9, kajian di analisis menggunakan analisis regresi logistik. Jika dilihat kepada nilai koefisien ketiga-tiga analisis tersebut, dapat dirumuskan daerah Kuala Terengganu dan daerah Kuala Nerus tiada pemboleh ubah yang signifikan. Seterusnya, gabungan dua daerah didapati juga tiada pemboleh ubah yang signifikan. Kesemua pemboleh ubah masing-masing signifikan pada aras keertian 5 peratus.

Ujian padanan menggunakan kaedah Hosmer and Lemeshow mencatatkan nilai Chi-Square bagi daerah Kuala Terengganu sebanyak 11.469 ( $\operatorname{sig}=0.177)$, daerah Kuala Nerus $6.412(\mathrm{sig}=0.601)$ dan kajian keseluruhan sebanyak 12.984 ( $\operatorname{sig}=0.112)$, kesemuanya dengan 8 darjah kebebasan. Kedudukan ini menunjukkan bahawa kajian mempunyai padanan yang baik dengan data. Namun begitu, nilai $\mathrm{R}^{2}$ pula yang menunjukkan variasi kesemua pemboleh ubah bagi ketiga-tiga tersebut dalam lingkungan sekitar 18.6 peratus hingga 25.4 peratus berasaskan Cox and Snell $\mathrm{R}^{2}$ dan Nagelkerke $\mathrm{R}^{2}$. Ini menunjukkan variasi pemboleh ubah bebas adalah agak bebas menerangkan pemboleh ubah bersandar.

Hasil kajian ini jelas menunjukkan dua sahaja pemboleh ubah yang signifikan dan perlu diberi perhatian berdasarkan pemerhatian terhadap ketiga-tiga analisis ini. (1) Faktor modal yang mencukupi menunjukkan ia adalah faktor yang berhubungan secara positif dan signifikan, menunjukkan kebarangkalian kecukupan modal yang diberikan menjamin kejayaan usahawan asnaf. (2) Faktor lokasi/premis perniagaan menunjukkan ia berhubungan positif dan signifikan, menunjukkan kebarangkalian penyediaan lokasi/premis perniagaan 
oleh pihak zakat di lokasi yang sesuai mampu membantu mereka pencapaian kejayaan perniagaan, di samping mendapat pulangan yang menguntungkan.

Jadual 9: Hasil Regresi Pencapaian Kejayaan Perniagaan Berasaskan Maqāșid al-Sharī'ah

\begin{tabular}{|c|c|c|c|}
\hline Pemboleh ubah & $\begin{array}{l}\text { Nilai Koefisien ( } \beta \text { ) } \\
\text { Kuala Terengganu }\end{array}$ & $\begin{array}{c}\text { Nilai Koefisien ( } \beta \text { ) } \\
\text { Kuala Nerus }\end{array}$ & $\begin{array}{c}\text { Nilai Koefisien ( } \beta \text { ) } \\
\text { Keseluruhan }\end{array}$ \\
\hline Konstan & $\begin{array}{c}-2.536 \\
(1.862) \\
{[1.862]}\end{array}$ & $\begin{array}{c}-11.825 \\
(5.870) \\
{[0.00]}\end{array}$ & $\begin{array}{c}-2.701 \\
(1.423) \\
{[3.603]}\end{array}$ \\
\hline Umur & $\begin{array}{l}-0.040 \\
(0.688) \\
{[0.003]}\end{array}$ & $\begin{array}{l}-1.200 \\
(0.544) \\
{[0.000]}\end{array}$ & $\begin{array}{c}0.273 \\
(0.527) \\
{[0.268]}\end{array}$ \\
\hline Pendidikan & $\begin{array}{c}-0.998 \\
(0.560) \\
{[3.178]}\end{array}$ & $\begin{array}{l}-3.129 \\
(1.434) \\
{[4.761]}\end{array}$ & $\begin{array}{c}-0.904 \\
(0.419) \\
{[4.652]}\end{array}$ \\
\hline Kesihatan & $\begin{array}{l}-0.345 \\
(0.599) \\
{[0.331]}\end{array}$ & $\begin{array}{l}-1.446 \\
(1.100) \\
{[1.730]}\end{array}$ & $\begin{array}{c}-0.563 \\
(0.441) \\
{[1.632]}\end{array}$ \\
\hline Tempoh berniaga & $\begin{array}{c}1.221 \\
(0.601) \\
{[4.135]}\end{array}$ & $\begin{array}{c}1.190 \\
(1.238) \\
{[0.924]}\end{array}$ & $\begin{array}{c}1.224 \\
(0.452) \\
{[7.339]}\end{array}$ \\
\hline $\begin{array}{l}\text { Modal yang } \\
\text { mencukupi }\end{array}$ & $\begin{array}{c}0.550 \\
(0.357) \\
{[2.378]}\end{array}$ & $\begin{array}{l}-0.568 \\
(0.859) \\
{[0.438]}\end{array}$ & $\begin{array}{c}0.475 \\
(0.261) \\
{[3.300]}\end{array}$ \\
\hline Pemasaran & $\begin{array}{c}0.265 \\
(0.240) \\
{[1.210]}\end{array}$ & $\begin{array}{c}0.653 \\
(0.791) \\
{[0.681]}\end{array}$ & $\begin{array}{c}0.288 \\
(0.201) \\
{[2.048]}\end{array}$ \\
\hline Tiada persaingan & $\begin{array}{c}0.170 \\
(0.252) \\
{[0.458]}\end{array}$ & $\begin{array}{c}0.701 \\
(0.538) \\
{[1.695]}\end{array}$ & $\begin{array}{c}0.217 \\
(0.202) \\
{[1.155]}\end{array}$ \\
\hline $\begin{array}{l}\text { Lokasi/Premis } \\
\text { perniagaan }\end{array}$ & $\begin{array}{c}0.073 \\
(0.238) \\
{[0.095]}\end{array}$ & $\begin{array}{c}-0.309 \\
(0.592) \\
{[0.272]}\end{array}$ & $\begin{array}{c}0.042 \\
(0.183) \\
{[0.053]}\end{array}$ \\
\hline $\begin{array}{l}\text { Kos operasi yang } \\
\text { rendah }\end{array}$ & $\begin{array}{l}-0.120 \\
(0.299) \\
{[0.162]}\end{array}$ & $\begin{array}{c}0.494 \\
(0.743) \\
{[0.442]}\end{array}$ & $\begin{array}{l}-0.100 \\
(0.244) \\
{[0.168]}\end{array}$ \\
\hline $\begin{array}{l}\text { Hosmer and } \\
\text { Lemeshow }(x)\end{array}$ & $11.469^{\mathrm{ns}}$ & $6.412^{\mathrm{ns}}$ & $12.984^{\text {ns }}$ \\
\hline Cox and Snell $\mathbf{R}^{2}$ & 0.166 & 0.382 & 0.186 \\
\hline Negelkerke $\mathbf{R}^{2}$ & 0.228 & 0.622 & 0.254 \\
\hline
\end{tabular}


Pengukuran Kejayaan Bantuan Modal Perniagaan Usahawan Asnaf dalam Konteks Pencapaian Maqāṣid al-Sharī'ah: Kajian di Daerah Kuala Terengganu dan Kuala Nerus, Terengganu

Nota: * signifikan pada aras keertian 5\%

ns tidak signifikan

( ) ralat piawai

[ ] ujian wald

Model regresi: Regresi binomial logistik. Pemboleh ubah

bersandar: Pencapaian kejayaan perniagaan berasaskan maqāṣid alsharī'ah

\section{PERBINCANGAN DAN IMPLIKASI DASAR}

Berdasarkan analisis keputusan didapati terdapat dua pemboleh ubah yang perlu diberikan perhatian oleh pihak MAIDAM dalam membantu asnaf berjaya dalam meningkatkan pendapatan mereka iaitu faktor modal yang mencukupi dan lokasi perniagaan. Para usahawan juga perlu mempunyai sikap yang tidak mudah putus asa, proaktif, keyakinan diri yang tinggi, inovatif dan sebagainya untuk lebih berjaya. Di samping itu, mereka perlu membaiki kemahiran pengurusan, menimba pengalaman sebanyak yang mungkin daripada jatuh dan bangun dalam sektor ini dan perlu mempunyai perancangan dan ilmu berkaitan dengan ekonomi dan kewangan. Hasil kajian ini juga mendapati beberapa pemboleh ubah yang diuji dalam model I yang tidak signifikan iaitu faktor umur, taraf pendidikan, tahap kesihatan, tempoh berniaga, pemasaran, tiada persaingan dan kos operasi yang rendah. Faktor umur pula berhubungan secara negatif dengan kebarangkalian kejayaan perniagaan yang mana semakin meningkat usia, semakin tinggi kebarangkalian kegagalan di dalam bidang perniagaan..$^{40}$ Ini juga menunjukkan golongan yang berumur agak sukar untuk menerima cabaran dan risiko. Mereka juga lebih gemar untuk melakukan sesuatu yang mudah bagi mereka iaitu seperti sesuatu yang tidak memerlukan pergerakan yang banyak, sesuatu yang mudah dipasarkan dan mudah dihasilkan.

Faktor taraf pendidikan dan tahap kesihatan menunjukkan pada hakikatnya bahawa perbezaan faktor tersebut tidak memberi pengaruh yang signifikan terhadap kejayaan bantuan modal. ${ }^{41}$ Sementara itu, tinggi atau rendah pendidikan formal yang dimiliki seseorang usahawan tidak signifikan mempengaruhi kerjayanya sebagai seorang usahawan tetapi ia

40 Rosbi Abd Rahman \& Sanep Ahmad, 'Strategi Pembangunan Keusahawanan Asnaf Fakir dan Miskin melalui Agihan Bantuan Modal Zakat,' 37-44.

41 Rosbi Abd Rahman, 'Keberkesanan Bantuan Modal Zakat Ke Arah Peningkatan Taraf Sosioekonomi Golongan Asnaf Fakir dan Miskin,' (Tesis Doktor Falsafah, Fakulti Ekonomi dan Pengurusan, Universiti Kebangsaan Malaysia, Bangi, 2011). 
sebenarnya terdorong daripada pendedahan latihan keusahawanan yang dapat menyumbang kepada peningkatan ilmu pengetahuan usahawan di samping membantu membentuk kemahiran mereka dalam perniagaan. ${ }^{42}$ Faktor tempoh berniaga tidak signifikan mempengaruhi kejayaan perniagaan mereka, di mana pengalaman berniaga kurang daripada tempoh lima tahun menyebabkan mereka sukar mengendalikan perniagaan dengan cekap. Ini kerana mereka kurang berpengalaman dalam selok belok di dalam bidang perniagaan. Bagi faktor pemasaran menunjukkan tidak memberi pengaruh yang signifikan terhadap kejayaan bantuan modal yang mana, kemungkinan tunjuk ajar dan perkongsian pendapat daripada jaringan kerjasama antara sesama usahawan dapat merancakkan aktiviti pemasaran mereka. Kerjasama dengan agensi kerajaan dapat membantu golongan berkenaan memasarkan produk mereka dengan lebih teratur dan sistematik melalui saluran pemasaran yang disediakan oleh agensi berkenaan. ${ }^{34}$ Faktor tiada persaingan tidak signifikan mempengaruhi kerjaya sebagai seorang usahawan. Hal ini disokong oleh kajian pengkaji ${ }^{43}$ yang mana faktor ini tidak signifikan dalam mempengaruhi kejayaan mereka. Selain, faktor kos operasi yang rendah tidak signifikan mempengaruhi kejayaan usahawan. Perkara ini kemungkinan kenaikan harga minyak yang semakin ketara dan lonjakan ekonomi yang amat tinggi telah mengundang kepada kos sara hidup diri yang kian meningkat. ${ }^{44}$ Kesannya akan dirasai oleh peringkat masyarakat yang berpendapatan rendah terutamanya golongan asnaf ini.

Namun, hasil kajian ini mendapati tiada satu faktor pun yang signifikan mempengaruhi kejayaan usahawan asnaf daripada aspek maqāṣid al-sharī'ah. Ini menunjukkan bahawa pencapaian maqāṣid al-sharī'ah itu adalah lebih bersifat dalaman yang berkait dengan falsafah jiwa yang kaya. Kejayaan untuk mencapai maqāșid al-sharī 'ah dalam kalangan usahawan tidaklah dipengaruhi secara langsung daripada faktor luaran seperti kecukupan modal, lokasi perniagaan, persaingan dan sebagainya yang lebih kepada faktor luaran yang

42 Buerah Tunggak, Hussin Salamon \& Baharin Abu, 'Pengaruh Faktor-Faktor Demografi Terhadap Budaya Niaga Usahawan Bumiputera Muslim,' Jurnal Kemanusiaan, vol. 10, no. 2 (2012): 17-31.

43 Hasnah Ali, Norhafizah Abdul Razak \& Sanep Ahmad, 'Faktor yang Mempengaruhi Usahawan Peruncitan Melayu: Satu Kajian Kes,' Prosiding PERKEM V, vol. 2 (2010): 141-151.

44 Hisham Sabri \& Zulkifli Hasan, 'Zakat: Instrumen Penyumbang Pembentukan Usahawan,' (Seminar Kebangsaan Pengurusan Harta dalam Islam, Kolej Islam Pahang Sultan Ahmad Shah (KIPSAS) Kuantan, 8-9 Ogos 2006). 
Pengukuran Kejayaan Bantuan Modal Perniagaan Usahawan Asnaf dalam Konteks Pencapaian Maqāṣid al-Sharī‘ah: Kajian di Daerah Kuala Terengganu dan Kuala Nerus, Terengganu

tidak boleh dikawal secara langsung oleh usahawan. Justeru strategi untuk meningkatkan kejayaan usahawan asnaf dalam mencapai maqāșid al-sharī'ah adalah lebih kepada penerapan pelbagai ilmu seperti ilmu fardu ain yang boleh membentuk sahsiah dan gelagat manusia termasuklah usahawan asnaf.

Apa yang menariknya kajian ini juga menunjukkan kebanyakan usahawan asnaf berasa lebih yakin untuk menjalankan perniagaan dengan adanya bantuan modal perniagaan daripada pihak MAIDAM. Ini menunjukkan mereka yakin dengan keberkatan sumber yang diperoleh selari dengan pandangan kajian ${ }^{45}$ yang menyatakan faktor keagamaan memberi kesan kepada kesihatan mental, mengubah sikap individu ke arah kehidupan yang lebih positif dan akhirnya mengubah gaya hidup seseorang dalam jangka masa panjang dan ini menepati pencapaian maqāssid al-sharī'ah yang telah digariskan dalam Islam. Kajian mendapati peratusan pencapaian maqāșid al-sharī'ah yang tinggi dalam kalangan asnaf yang menerima bantuan modal perniagaan adalah menjaga agama, menjaga aqal dan fikiran serta menjaga maruah dan keturunan yang mana masing-masing adalah 58.6 peratus, 43.6 peratus dan 42.1 peratus. Walaupun kejayaan bantuan modal dalam aspek peningkatan pendapatan tidak berlaku, namun sekurang-kurangnya kejayaan mereka mencapai keperluan maqāșid al-sharī'ah juga perlu diberi pengiktirafan. Hal ini ditambah lagi dengan pandangan kajian pengkaji ${ }^{46}$ bahawa suntikan modal daripada pihak MAIDAM akan menambah keyakinan mereka dengan keberkatan sumber modal yang diperoleh. Oleh itu, kajian ini akan mencadangkan pemberian bantuan modal perniagaan daripada MAIDAM kepada golongan ini supaya golongan ini tidak disisihkan daripada masyarakat berikutan kesukaran mereka mendapatkan bantuan untuk meneruskan kehidupan di luar. Diharapkan juga walaupun mereka tidak menjadi seorang usahawan berjaya, tetapi sekurangkurangnya bantuan ini yang diberikan dapat memenuhi tuntutan maqāșid alsharì'ah dan mendidik mereka menjadi insan yang kaya jiwa walaupun tanpa harta yang banyak.

Antara cadangan yang difikirkan sesuai adalah pihak MAIDAM perlu terus memantau usahawan asnaf agar mereka dapat mengekalkan prestasi perniagaan

45 Hairunnizam Wahid, Sanep Ahmad, \& Radiah Abdul Kader, 'Pengaruh Faktor Keagamaan Terhadap Kualiti Hidup Individu: Kajian Kes Asnaf Fakir dan Miskin,' 496.

46 Khairani, Ima M., Hairunnizam Wahid, \& Sanep Ahmad, 'Cadangan Bantuan Zakat Asnaf Al-Riqab Terhadap Banduan Melalui Latihan Vokasional di Penjara: Kajian di Penjara Wanita Kajang, Selangor,' (Kertas Kerja, Seminar Fiqh Semasa (Sefis), Universiti Sains Islam Malaysia, 2015), 48. 
dari semasa ke semasa. Oleh itu, pihak MAIDAM boleh juga menganjurkan beberapa program keusahawanan kepada usahawan asnaf yang berpotensi contohnya, projek usahawan berkelompok dengan menubuhkan bengkel luar yang mana mereka diberikan gaji berdasarkan kerja yang mereka hasilkan ataupun menyediakan tempat untuk mereka berniaga secara kecil-kecilan serta membantu memasarkan produk yang dihasilkan. Selain itu, dicadangkan juga usahawan asnaf ini mewujudkan jaringan sosial dan kerjasama yang kukuh dalam kalangan rakan perniagaan dan masyarakat. Mereka juga perlu menambahkan ilmu berkaitan pemasaran dengan menghadiri seminar dan program-program yang berkaitan melalui agensi-agensi kerajaan yang dipertanggungjawabkan. Justeru bantuan, sokongan serta polisi-polisi yang telah dijalankan oleh kerajaan sebelum ini melalui agensi-agensi yang berkaitan perlu diteruskan dan dibuat penambahbaikan selaras dengan matlamat kerajaan untuk membangunkan ekonomi bumiputera di negara ini.

Usaha yang telah dilaksanakan oleh pihak berkuasa zakat dalam membangunkan usahawan asnaf zakat khususnya di bidang ekonomi ini wajar diteruskan. Oleh itu, kajian mencadangkan agar pihak MAIDAM memberi bantuan modal perniagaan kepada golongan ini bagi tujuan memajukan diri. Di samping itu, pihak MAIDAM perlu sentiasa membuat pemantauan dan menganjurkan program motivasi secara berkala supaya golongan ini tidak akan lalai serta dalam menjalankan amanah yang diberikan. Ia juga bertujuan untuk memastikan pencapaian maqūșid al-sharī'ah daripada sudut menjaga agama terus dipelihara. Diharapkan dengan adanya program bantuan modal perniagaan ini mampu untuk mengeluarkan mereka daripada terus dibelenggu oleh kemiskinan dan dapat menjalani kehidupan normal seperti masyarakat lain.

\section{KESIMPULAN}

Hasil kajian menunjukkan bahawa selain keberkesanan kejayaan atau matlamat program bantuan zakat perniagaan dalam membasmi kemiskinan asnaf yang menunjukkan indikator kejayaan yang sederhana, terdapat faktor-faktor lain yang dikenal pasti mempengaruhi kejayaan perniagaan. Faktor tersebut tentunya perlu diberi perhatian oleh pihak berkuasa zakat untuk meningkatkan lagi kebarangkalian kejayaan perniagaan golongan usahawan asnaf tersebut. Tumpuan kepada aspek modal sahaja merupakan satu kepincangan. Oleh itu, kajian ini menunjukkan bahawa pemberian modal perniagaan perlu disertakan dengan faktor lain bagi menjadikannya lengkap yang dapat menjamin kejayaan. Bantuan modal ini pastinya diharapkan berupaya untuk membantu 
Pengukuran Kejayaan Bantuan Modal Perniagaan Usahawan Asnaf dalam Konteks Pencapaian Maqāșid al-Sharī'ah: Kajian di Daerah Kuala Terengganu dan Kuala Nerus, Terengganu

usahawan asnaf meningkatkan taraf kehidupan mereka di masa akan datang dalam jangka panjang dan seterusnya berjaya mentransformasikan diri mereka dari seorang penerima bantuan modal perniagaan kepada pembayar zakat.

\section{RUJUKAN}

Ahmad Fadzly Esa, 'LZS Sasar Kutipan, Agihan Zakat RM645 juta,'Berita Harian Online, 4 Februari 2016.

Ahmad Mahdzan Ayob, Perancangan dan Penilaian Projek Pembangunan (Kuala Lumpur: Dewan Bahasa dan Pustaka, 1989).

Ang, James S, 'Small Business Uniqueness and the Theory of Financial Management,' Journal of Small Business Finance, vol. 1/1 (1991): 1113.

Azman, A.R, Mohamad Yazis, Mahdhir, Mohammad Noorizzudin \& Ahmad Anis, 'Keberkesanan Program Usahawan Asnaf Oleh Institusi Zakat dalam Menginterpretasikan Keharmonian Ummah,' (International Conference on Arabic Studies and Islamic Civilization iCasic, Kuala Lumpur, 4-5 Mac 2014).

Buerah Tunggak, Hussin Salamon \& Baharin Abu, 'Pengaruh Faktor-Faktor Demografi Terhadap Budaya Niaga Usahawan Bumiputera Muslim,' Jurnal Kemanusiaan, vol. 10, no. 2 (2012): 17-31.

Busenitz, L. W., Gomez, C. \& Spencer, J. W., 'Country institutional profiles: Unlocking Entrepreneurial Phenomena', Academy of Management Journal, 43/5 (2002): 994-1003.

Byrd, M. J. \& Megginson, L. C, Small Business Managament: An Entrepreneur's Guidebook, $7^{\text {rd }}$ ed. (New York: Irwan McGraw-Hill, 2013)

Delmar, F., 'The Psychology of the Entrepreneur,' in Enterprise and Small Business: Principles, Practice and Policy, ed. S. Carter \& D. JonesEvans (Harlow: Financial Times, 2000).

Fuadah Johari, 'Keberkesanan Zakat dalam Mengatasi Masalah Kemiskinan di Negeri Melaka,' (Disertasi Sarjana, Jabatan Syariah dan Ekonomi, Akademi Pengajian Islam, Universiti Malaya, Kuala Lumpur, 2004).

Hairunnizam Wahid, Sanep Ahmad, \& Radiah Abdul Kader, 'Pengaruh Faktor Keagamaan Terhadap Kualiti Hidup Individu: Kajian Kes Asnaf Fakir dan Miskin,' (Kertas kerja, Seminar Kebangsaan MACFEA ke-14: Hala tuju Penyelidikan Kepenggunaan, 13-14 Julai 2010). 
Hasbullah Mat Daud, 'Teori Maqasid al-Syari'ah: Kajian Perbandingan Antara Pemikiran al-Shatibi dan 'Izz al-Dīn Ibn 'Abd al-Salām' (Disertasi Sarjana, Jabatan Fiqh dan usul, Akademi Pengajian Islam, Universiti Malaya, Kuala Lumpur, 2011).

Hasnah Ali, Norhafizah Abdul Razak \& Sanep Ahmad, 'Faktor yang Mempengaruhi Usahawan Peruncitan Melayu: Satu Kajian Kes,' Prosiding PERKEM V, vol. 2 (2010): 141-151.

Hisham Sabri \& Zulkifli Hasan, 'Zakat: Instrumen Penyumbang Pembentukan Usahawan,' (Seminar Kebangsaan Pengurusan Harta dalam Islam, Kolej Islam Pahang Sultan Ahmad Shah (KIPSAS) Kuantan, 8-9 Ogos 2006).

Kets de Vries \& Manfred, F. R, 'The Entrepreneurial Personality: A Person at the Cross Roads', Journal of Managerial Studies, vol. 14/1 (1977): 34-57.

Khairani, Ima M., Hairunnizam Wahid, \& Sanep Ahmad, 'Cadangan Bantuan Zakat Asnaf Al-Riqab Terhadap Banduan Melalui Latihan Vokasional di Penjara: Kajian di Penjara Wanita Kajang, Selangor,' (Kertas Kerja, Seminar Fiqh Semasa (Sefis), Universiti Sains Islam Malaysia, 2015).

Kuratho, D.F. \& Hodgetts, R.M., Entrepruneurship: Theory, Process and Practice (Ohio: South Western, 2004).

Lamsa, A. M., \& Savolainen, T., 'The Nature of Managerial Commitment to Strategies Change', Journal of Leadership \& Organization Development, vol. 21/6 (2000): 102-119.

M. Umer Chapra, The Islamic Vision of Development in the Light of the Maqasid al-Syari'ah (Jeddah, Kingdom of Saudi Arabia: Islamic Research and Training Institute, Islamic Development Bank, 2008).

Mahmood Zuhdi Abd Majid, Pengurusan Zakat (Kuala Lumpur: Dewan Bahasa dan Pustaka, 2003).

Martinelli, A., Entrepreneurs and Management. In: Sociology (Princeton, N.J.: Princeton University Press, 1994).

Muḥammad Ibn Aḥmad Ibn Muḥammad Ibn Aḥmad Ibn Rushd al-Qurțūbī, al-Jāmi' li Aḥkām al-Qur'ān, vol. 6 (Bayrūt: Dar al-Kutub al-'Ilmiyyah, 1996).

Noor Ghani Md. Nor, Abd. Razak \& Mohd Ali Mohd Nor, 'The Contribution of Zakat as An Income Creating Asset in Selangor and Wilayah Persekutuan, Malaysia,' Jurnal Ekonomi Malaysia, vol. 36 (2002): 6980. 
Pengukuran Kejayaan Bantuan Modal Perniagaan Usahawan Asnaf dalam Konteks Pencapaian Maqāșid al-Sharī'ah: Kajian di Daerah Kuala Terengganu dan Kuala Nerus, Terengganu

Norashidah Hashim, Norsiah Othman \& Noraishah Buang, 'Konsep Kesediaan Keusahawanan Berdasarkan Kajian Kes Usahawan Industri Kecil dan Sederhana (IKS) di Malaysia', Jurnal Pendidikan Malaysia, vol. 34/1 (2009): 187-203.

Norsidah Ahmad, 'Factors Affecting Business Performance of Malay Women Entrepreneurs in the Klang Valley,' (Master Dissertation, Universiti Sains Malaysia, Pulau Pinang, 1999).

Pusat Pungutan Zakat, Majlis Agama Islam Wilayah Persekutuan, Laporan Zakat (Kuala Lumpur: Daruzzakah, 2006).

Rahmah Ismail, Nor Aini Hj Idris, Mohd Nasir Mohd Saukani \& Norasiah Sulaiman. Daya Saing Usahawan dan Syarikat Melayu dalam Sektor Pembuatan dan Perkhidmatan (Kuala Lumpur: Dewan Bahasa dan Pustaka, 2006)

Al-Raysun̄̄, Aḥmad, Naẓariyyat al-Maqāș̣id 'ind al-Imām al-Shāṭibī (Qāhirah: Dār al-Kalimah, 2015).

Rohaizat Baharun, 'Kejayaan Para Usahawan Daripada Perspektif Penyelidikan,' Dewan Ekonomi (Januari, 2000).

Rosbi Abd Rahman \& Sanep Ahmad, 'Strategi Pembangunan Keusahawanan Asnaf Fakir dan Miskin melalui Agihan Bantuan Modal Zakat,' Jurnal Pengurusan, vol. 33 (2011): 37-44.

Rosbi Abd Rahman, 'Keberkesanan Bantuan Modal Zakat Ke Arah Peningkatan Taraf Sosioekonomi Golongan Asnaf Fakir dan Miskin,' (Tesis Doktor Falsafah, Fakulti Ekonomi dan Pengurusan, Universiti Kebangsaan Malaysia, Bangi, 2011).

Rosbi Abd Rahman, Sanep Ahmad \& Hairunnizam Wahid, 'Pelaksanaan Bantuan Modal Zakat: Analisis Perbandingan,' (Kertas Kerja, Seminar Kebangsaan Ekonomi Malaysia IV, Fakulti Ekonomi dan Perniagaan, Universiti Kebangsaan Malaysia, Port Dickson, 20-22 Ogos 2008).

Rossi, P.H., Lipsey, M.W \& Freaman, H.E., Evaluation A Systematic Approach, $7^{\text {th }}$ ed. (California: Sage Publishers, Inc, 2004).

Al-Shātibī, Abū Ishāa Ibrahim bin Mūsā Ibn Muhammad al-Lakhmī, alMuwāfaqāt fì Ușūl al-Sharī'ah, vol. 1-2 (Bayrūt: Dār al-Kutub al'Ilmiyyah, 2001).

Sukor Kasim, 'Peranan Modal dalam Membasmi Kemiskinan,' (Kertas Kerja, Konvensyen Ekonomi Bumiputera; Prestasi Kini dan Cabaran Selepas 1990, 12-13 November 1990). 
Supardi, 'Zakat Organization and Poverty Alleviation; A Macro Social Work and Community Development Perspectives,' (Master Dissertation, School of Graduate Studies, State Islamic University Sunan Kalijaga, Yogyakarta, 2005).

Wehr, Hans, A Dictionary of Modern Written Arabic (London: McDonald \& Evan Ltd., 1980).

Xavier, John Antony, Effective Evaluation: A Practical Guide (Kuala Lumpur: National Institute of Public Administration (INTAN), 2000).

Zuraini Zakaria, 'Faktor-faktor yang Mempengaruhi Kemampuan Usahawan Bumiputera di kawasan Sungai Petani Kedah dalam Memajukan Perniagaan Mereka,' (Latihan Ilmiah, Sarjana Muda, Universiti Teknologi Malaysia, Skudai, 2000). 